\title{
Uji Antibakteri Fraksi Aktif Ekstrak Aseton Kulit Batang Shorea acuminatissima terhadap Staphylococcus aureus dan Pseudomonas aeruginosa Multiresisten antibiotik
}

\section{Antibacterial Activity of Active Fraction Aceton Extract from Shorea accuminatissima to Staphylococcus aureus and Pseudomonas aeruginosa Multiple Resistance Antibiotic}

\author{
Imam Prayitno ${ }^{1)}$, Haryoto Saroyobudiyono ${ }^{2)}$, Peni Indrayudha ${ }^{3)}$ \\ ${ }^{1,2,3)}$ Fakultas Farmasi Universitas Muhammadiyah Surakarta \\ 1, 2, 3) Surakarta; imamapt@gmail.com
}

\section{Intisari}

Penyakit infeksi merupakan masalah serius di Indonesia, termasuk di dalamnya resistensi mikroba terhadap obat-obatan yang ada. Salah satu tumbuhan hutan tropis Indonesia adalah Shorea accuminatissima yang termasuk dalam famili Dipterocarpaceae dan dilaporkan mempunyai kandungan senyawa fenolik dengan aktivitas biologi seperti antibakteri, antioksidan dan antifungi. Penelitian ini bertujuan untuk mengetahui aktivitas antibakteri dari ekstrak aseton dan fraksi aktif ekstrak aseton terhadap $S$. aureus dan $P$. aeruginosa multiresisten antibiotik.

Ekstrak aseton diperoleh dengan metode maserasi, selanjutnya diuji aktivitas antibakterinya. Ekstrak aseton difraksinasi menggunakan kromatografi cair vakum (KCV). Setiap fraksi diuji bioautografi untuk melihat aktivitas antibakterinya menggunakan metode filter paper disk dengan bakteri uji $S$. aureus dan $P$. aeruginosa. Fraksi dengan zona hambat terbesar merupakan fraksi aktif Kemudian dilakukan uji aktivitas antibakteri fraksi aktif ekstrak aseton. Kadar terkecil yang dapat menghambat pertumbuhan bakteri disebut sebagai kadar bunuh minimum (KBM).

Hasil penelitian menunjukkan ekstrak aseton kulit batang Shorea accuminatissima mempunyai nilai KBM 0,25\% b/v terhadap $S$. aureus multiresisten antibiotik dan nilai KBM $1 \% \mathrm{~b} / \mathrm{v}$ terhadap $P$. aeruginosa multiresisten antibiotik. Fraksi aktif adalah fraksi C. Fraksi aktif mempunyai nilai KBM $0,125 \%$ b/v terhadap $S$. aureus multiresisten antibiotik dan nilai KBM 0,25\% b/v terhadap $P$. aeruginosa multiresisten antibiotik.

Kata kunci: Shorea accuminatissima, bioautografi fraksi aktif, $\mathbf{S}$. aureus danP. Aerugin osa multiresisten antibiotik, KBM

\begin{abstract}
Infection disease has a serious problem in Indonesia, including antibiotic resistance of microorganisms. One of the tropical forest plant in Indonesia is Shorea accuminatissima which included in Dipterocarpaceae and reported to have compound content of phenolic
\end{abstract}


with biological activity like antibacterial, antioxidant and antifungi. This research aim to know the antibacterial activities of acetone extract and active fraction of acetone extract to $S$. aureus and $P$. aeruginosa multiple resistance antibiotic.

Acetone extract obtained with maceration method, then tested the antibacterial activity. Later, acetone extract fractioned use Vacuum Liquid Chromatography (VLC). Each fraction tested by bioautographic to determine the antibacterial activities using a filter paper disc method with $S$. aureus and $P$. aeruginosa. Fraction with the biggest radical zone is an active fraction, then tested the antibacterial activity. The lowest concentration that kills bacterial growth conceived as Minimum Bactericidal Concentration (MBC).

Research show that acetone extract of Shorea accuminatissima stembark have the MBC values at $0,25 \%$ to $S$. aureus multiple resistance antibiotic and $1 \%$ to $P$. aeruginosa multiple resistance antibiotic. Active fraction is fraction C. Active fraction have the MBC values at $0,125 \%$ to $S$. aureus multiple resistance antibiotic and $0,25 \%$ to $P$. aeruginosa multiple resistance antibiotic.

Keywords: Shorea accuminatissima, bioautographic active fraction, $S$. aureus and $P$. aeruginosa multiple resistance to antibiotic.

\section{Pendahuluan}

Penyakit infeksi merupakan salah satu masalah dalam bidang kesehatan yang dari waktu ke waktu terus berkembang (Gibson, 1996). Staphylococcus merupakan penyebab penting penyakit infeksi. Dalam keadaan normal Staphylococcus terdapat di saluran pernafasan atas, kulit, saluran cerna dan vagina. Staphylococcus dapat menimbulkan penyakit terutama bila daya tahan tubuh hospes sedang turun, misalnya sedang menderita infeksi virus atau ada benda asing. Infeksi kulit Staphylococcus mungkin termasuk penyakit infeksi yang paling sering, misalnya, lebih dari 1,5 juta kasus furunkulosis terjadi di Amerika Serikat setiap tahunnya (Shulman et al., 1994). Bakteri lain yang juga berbahaya adalah Psendomonas aeruginosa. Psendomonas aeruginosa menyebabkan infeksi pada luka dan luka bakar, menghasilkan nanah warna hijau biru, meningitis jika masuk melalui fungsi lumbal, dan infeksi saluran kencing jika masuk melalui kateter dan instrumen atau karena larutan irigasi (Jawetz et al., 2001).

Dalam pengobatan penyakit infeksi, masalah yang sering timbul adalah terjadinya resistensi. Resistensi bakteri terhadap antibiotik membawa masalah tersendiri yang dapat menggagalkan terapi antibiotik
(Wattimena, 1991). Meluasnya resistensi mikroba terhadap obat-obatan yang ada, mendorong pentingnya penggalian sumber antimikroba dari bahan alam. Tanaman obat diketahui potensial dikembangkan lebih lanjut pada penyakit infeksi namun masih banyak yang belum dibuktikan aktivitasnya secara ilmiah (Hertiani et al., 2003 ).

$\begin{array}{crr}\text { Isolasi dan identifikasi } & \text { senyawa } \\ \text { stilbenoid dari tumbuhan } & \text { famili }\end{array}$ Dipterocarpaceae telah banyak dilaporkan (Sotheeswaran and Pasupathy, 1993). Senyawa-senyawa stilbenoid dilaporkan memiliki berbagai aktivitas biologis yang menarik, salah satunya adalah distichol yang diisolasi dari Shorea disticha sebagai antibakteri (Sultanbawa et al., 1987). Shorea accuminatissima termasuk dalam famili Dipterocarpaceae sehingga diperkirakan mengandung senyawa stilbenoid yang mempunyai aktivitas antibakteri. Beberapa oligostilbenoid atau resveratrol seperti shoreaketon berhasil diisolasi dari ekstrak aseton Shorea uliginosa (Ito et al., 2005). Selain itu, vateriafenol A dan vateriafenol $\mathrm{B}$ juga berhasil diisolasi dari ekstrak aseton Vateria indica (Ito et al., 2003). 
Berdasarkan data-data dari penelitian tersebut, pada penelitian ini akan dilakukan fraksinasi ekstrak aseton kulit batang meranti kuning (Shorea accuminatissima) dengan metode Kromatografi Cair Vakum untuk mengetahui pada fraksi manakah ekstrak aseton kulit batang meranti kuning (Shorea accuminatissima) tersebut beraktivitas sebagai antibakteri terhadap Staphylococcus aureus dan Pseudomonas aeruginosa multiresisten antibiotik. Penelitian ini bertujuan untuk mengetahui aktivitas antibakteri fraksi aktif ekstrak aseton kulit batang meranti kuning (Shorea accuminatissima) terhadap Staphylococcus aureus dan Pseudomonas aeruginosa multiresisten antibiotik.

\section{Metode Penelitian}

\section{Bahan}

Bahan yang digunakan dalam penelitian ini adalah kulit batang Shorea accuminatissima wilayah HPH PT Aya Yayang Indonesia Camp 63, Tanjung, Tabalong, Kalimantan Selatan, aseton teknis, etil asetat teknis, n-heksan teknis. silika gel $\mathrm{GF}_{254}$ (Merck), S. aureus ATCC 25923, P.aeruginosa ATCC 27853, aquadest steril, media Mueller Hinton (Merck), media Brain Heart Infusion (Merck), filter paper disk steril, DMSO p.a. dan Standard Mc. Farland (konsentrasi $10^{8} \mathrm{CFU} /$ $\mathrm{mL})$.

\section{Alat \\ Alat yang digunakan dalam penelitian ini adalah seperangkat alat gelas, alat timbang, alat maserasi, rotary evaporator, kolom KCV, cawan petri, yellow tips, blue tips, pipet tetes, ose steril, pinset, oven, autoklaf, lampu spiritus, labu takar, mikropipet, tabung reaksi, rak tabung.}

\section{Jalannya Penelitian}

\section{Determinasi Tanaman}

Determinasi dilakukan di laboratorium Herbarium Bogoriense, Balai Penelitian dan Pengembangan Biologi, LIPI, Bogor, Indonesia, dan spesimen disimpan di Herbarium tersebut.

\section{Penyiapan Bahan}

Kulit batang meranti kuning (Shorea accuminatissima) dibersihkan, dikeringkan kemudian diserbuk untuk memperoleh ukuran partikel yang lebih kecil.

\section{Penyarian Bahan (serbuk)}

Simplisia kulit batang meranti kuning (Shorea accuminatissima) sebanyak 10 bagian yaitu $3 \mathrm{~kg}$ disari dalam minimal 75 bagian penyari yaitu aseton 22,50 liter. Remaserasi dilakukan dengan cara serbuk sampel sebanyak $3 \mathrm{~kg}$ direndam selama 24 jam menggunakan 8 liter aseton dan selama perendaman dilakukan proses pengadukan. Semua sari yang diperoleh diuapkan sampai kental dengan menggunakan rotary evaporator, kemudian dikeringanginkan pada suhu kamar sampai bau asetonnya hilang.

4. Pemilihan Fase Gerak untuk Fraksinasi Pemilihan dilakukan dengan metode KLT preparatif menggunakan campuran pelarut organik yaitu nheksana dan etil asetat dengan berbagai perbandingan.

\section{Fraksinasi Ekstrak Aseton}

Pemasukan sampel ke dalam kolom KCV dilakukan dalam bentuk teradsorpsi atau diimpregnasikan ke dalam silika gel G 60 dengan perbandingan berat sampel terhadap silika gel minimum $1: 2$. Pada penelitian ini digunakan silika gel $G$ 60 sebanyak 50 gram dengan berat sampel 25 gram. Fase gerak yang digunakan adalah n-heksan, etil asetat dan metanol dengan perbandingan volume yang bervariasi (Tabel 1).

Elusi dilakukan dengan fase gerak sebanyak $200 \mathrm{~mL}$. Urutan pemberian fase gerak seperti pada Tabel 1. Tiap tampungan diperiksa dengan Kromatografi Lapis Tipis (KLT) untuk kemudian dikelompokkan berdasarkan profil kromatogram yang sama. 
Tabel 1. Fase Gerak untuk Elusi pada Fraksinasi Ekstrak Aseton

\begin{tabular}{cccc}
\hline No & Perbandingan pelarut & Elusi & Volume Penambahan \\
\hline 1 & n-heksan : etil asetat (5:5) & 2 kali & $200 \mathrm{~mL}$ \\
2 & n-heksan : etil asetat (4:6) & 4 kali & $200 \mathrm{~mL}$ \\
3 & n-heksan : etil asetat (3:7) & 4 kali & $200 \mathrm{~mL}$ \\
4 & n-heksan : etil asetat (2:8) & 4 kali & $200 \mathrm{~mL}$ \\
5 & n-heksan : etil asetat (1:9) & 2 kali & $200 \mathrm{~mL}$ \\
6 & Metanol 100\% & 1 kali & $200 \mathrm{~mL}$ \\
\hline
\end{tabular}

\section{Sterilisasi Alat dan Bahan}

Alat-alat gelas yang digunakan untuk uji aktivitas antibakteri disterilkan dalam oven dan bahan-bahan yang digunakan, yellow dan blue tips disterilkan dalam autoclave, sedangkan ose disterilkan dengan memanaskannya pada api sesaat sebelum digunakan.

\section{Penyiapan Suspensi Bakteri}

Diambil beberapa koloni bakteri dari biakan murni, kemudian ditanam pada media Mueller Hinton dan diinkubasi $37^{\circ} \mathrm{C}$ selama $18-24$ jam.

Dengan ose steril dambil koloni lalu ditanam pada $2 \mathrm{~mL}$ BHI cair dan diinkubasi selama 4-8 jam kemudian disesuaikan dengan standard Mc. Farland sampai diperoleh suspensi bakteri $10^{6}$ $\mathrm{CFU} / \mathrm{mL}$.

\section{Penyiapan Kontrol}

Kontrol 1 merupakan kontrol negatif pertumbuhan yang berisi hanya media MH. Kontrol 2 berisi media MH yang diinokulasi suspensi bakteri sebagai kontrol positif pertumbuhan bakteri. Kontrol 3 berisi media $\mathrm{MH}$ yang telah dicampur dengan DMSO 5\% dan diberi suspensi bakteri digunakan untuk mengetahui pengaruh pelarut DMSO 5\% terhadap pertumbuhan bakteri. Ketiga kontrol tersebut diinkubasi pada suhu $37^{\circ} \mathrm{C}$ selama $18-24$ jam.

9. Uji Pendahuluan aktivitas antibakteri ekstrak aseton kulit batang meranti kuning terhadap $S$. aureus ATCC $25923, P$. aeruginosa ATCC $27853, S$. aureus dan $P$. aeruginosa multiresisten antibiotik.

Larutan stok ekstrak kadar 4\% b/v dibuat. Lima seri kadar dibuat dari larutan stok dengan kadar masing-masing $4 \% ; 2 \% ; 1 \% ; 0,5 \% ; 0,25 \% \mathrm{~b} / \mathrm{v}$ untuk uji terhadap S. aureus ATCC 25923 dan $P$. aeruginosa ATCC 27853 dan enam seri kadar dibuat dari larutan stok dengan kadar masing-masing 4\%; $2 \% ; \quad 1 \%$; $0,5 \% ; \quad 0,25 \% ; \quad 0,125 \% \mathrm{~b} / \mathrm{v}$ untuk uji terhadap $S$. aureus dan $P$. aeruginosa multiresisten antibiotik. Suspensi bakteri $10^{6} \mathrm{CFU} / \mathrm{mL}$ diambil $25 \mu \mathrm{L}$, kemudian ditanamkan pada masing-masing tabung yang mengandung seri konsentrasi ekstrak yang berbeda. Setelah itu diinkubasi selama 18-24 jam pada suhu $37^{\circ} \mathrm{C}$ dan diamati hasilnya. Pengujian ini direplikasi sebanyak tiga kali.

Hasil pengamatan uji aktivitas antibakteri terhadap $S$. aureus ATCC 25923 menunjukkan bahwa sampai kadar terkecil yaitu $0,25 \% \quad \mathrm{~b} / \mathrm{v}$ tidak diketemukan adanya pertumbuhan bakteri. Maka dilakukan uji lanjutan aktivitas antibakteri terhadap $S$. aureus ATCC 25923 dengan seri konsentrasi $0,25 \% ; \quad 0,125 \% ; \quad 0,0625 \% ; \quad 0,03125 \%$ b/v. Suspensi bakteri $10^{6} \mathrm{CFU} / \mathrm{mL}$ diambil $25 \mu \mathrm{L}$, ditanamkan pada masingmasing tabung yang mengandung seri konsentrasi yang berbeda. Setelah itu diinkubasi selama 18-24 jam pada suhu $37^{\circ} \mathrm{C}$ dan diamati hasilnya. Pengujian ini direplikasi sebanyak tiga kali.

10. Bioautografi Fraksi Aktif Antibakteri Beberapa fraksi dari ekstrak aseton kulit batang meranti kuning, dilakukan bioautografi dengan metode filter paper disk. Masing-masing fraksi dibuat stok sediaan konsentrasi $25 \mathrm{mg} / \mathrm{mL}$ dengan melarutkan $25 \mathrm{mg}$ fraksi dalam $1 \mathrm{~mL}$ aseton. Stok sediaan diambil $100 \mu \mathrm{L}$ dan diimpregnasikan 
pada disk kertas saring steril berdiameter $7 \mathrm{~mm}$ sehingga masing-masing disk kertas saring mengandung fraksi 2,5 $\mathrm{mg}$ kemudian disk kertas saring tersebut diletakkan pada permukaan media $\mathrm{MH}$ yang sebelumnya telah diinokulasi dengan S. aureus ATCC 25923 dan P. aeruginosa ATCC 27853 diinkubasi pada suhu $37^{\circ} \mathrm{C}$ selama 18-24 jam. Diamati zona hambatan yang terbentuk. Fraksi dengan zona hambat terbesar adalah fraksi yang mempunyai aktivitas antibakteri terbaik dan disebut sebagai fraksi aktif.

11. Uji Aktivitas Antibakteri Fraksi Aktif ekstrak aseton kulit batang meranti kuning terhadap $S$. aureus ATCC 25923, $P$. aeruginosa ATCC 27853, $S$. aureus dan $P$. aeruginosa multiresisten antibiotik.

Larutan stok fraksi aktif antibakteri kadar $1 \% \mathrm{~b} / \mathrm{v}$ dibuat. Lima seri kadar dari larutan stok dibuat dengan kadar masing-masing $1 \% ; 0,5 \% ; 0,25 \%$; $0,125 \% ; 0,0625 \% \mathrm{~b} / \mathrm{v}$ pada tabung steril. $\quad 25 \mu \mathrm{L}$ suspensi bakteri $10^{6}$ $\mathrm{CFU} / \mathrm{mL}$ diambil, kemudian ditanamkan pada masing-masing tabung yang mengandung lima seri konsentrasi fraksi aktif yang berbeda. Setelah itu diinkubasi selama 18 -24 jam pada suhu $37^{\circ} \mathrm{C}$ dan diamati hasilnya. Pengujian ini direplikasi sebanyak tiga kali.

12. Analisis Data

Data diperoleh dengan melakukan pengamatan ada tidaknya pertumbuhan bakteri pada media Mueller Hinton, dibandingkan dengan kontrol positif dan negatif. Kadar terkecil yang dapat membunuh bakteri disebut kadar bunuh minimum (KBM).

\section{Hasil dan Pembahasan}

Determinasi tanaman dilakukan di laboratorium Herbarium Bogoriense Balai Penelitian dan Pengembangan Biologi, LIPI, Bogor, Indonesia, dan spesimen disimpan di
Herbarium tersebut. Hasil determinasi yang dilakukan, didapatkan bahwa tanaman tersebut adalah Shorea accuminatissima.

Simplisa kulit batang Shorea accuminatissima yang telah diserbuk, diekstraksi dengan cara maserasi menggunakan larutan penyari aseton teknis. Maserasi dipilih karena merupakan ekstraksi cara dingin sehingga kerusakan senyawa yang terkandung di dalam simplisia dapat diperkecil dengan tidak adanya faktor panas.

Penyarian dimulai dengan merendam serbuk simplisia dengan larutan penyari aseton. Aseton merupakan pelarut yang dapat menarik senyawa senyawa metabolit sekunder yang dihasilkan oleh Shorea yaitu senyawa polifenol (Noviany, et al, 2003).

Pada saat maserasi yang harus diperhatikan adalah kondisi kesetimbangan, ketika aseton telah mencapai konsentrasi tertentu sehingga tidak lagi mampu menarik zat aktif. Hal tersebut dapat diminimalkan dengan menggantikan aseton setiap hari selama tiga hari. Setiap 24 jam dilakukan penyaringan dengan menggunakan kain flanel, filtrat yang diperoleh diuapkan sampai kental.

Hasil uji aktivitas antibakteri ekstrak aseton kulit batang meranti kuning terhadap S. aureus ATCC 25923 dan S. aureus multiresisten antibiotik menunjukkan bahwa ekstrak aseton memberikan nilai KBM sebesar $0,25 \%$ b/v sedangkan hasil uji aktivitas antibakteri ekstrak aseton kulit batang meranti kuning dapat terhadap $P$. aeruginosa ATCC 27853 dan P. aeruginosa multiresisten antibiotik menunjukkan bahwa ekstrak aseton memberikan nilai KBM sebesar $1 \% \mathrm{~b} / \mathrm{v}$. Hasil tersebut dapat dilihat pada Tabel 2. Berdasarkan pada hasil uji tersebut maka penelitian dilanjutkan dengan melakukan uji aktivitas antibakteri pada fraksi dari ekstrak aseton kulit batang meranti kuning (Shorea accuminatissima). 
Tabel 2. Hasil Uji Aktivitas Antibakteri Ekstrak Aseton Kulit Batang Meranti Kuning (Shorea accuminatissima) terhadap $S$. aureus ATCC 25923, P. aeruginosa ATCC 27853, S. aureus dan $P$. aeruginosa Multiresisten Antibiotik.

\begin{tabular}{cccccc}
\hline $\begin{array}{c}\text { Konsentrasi } \\
\text { b/v) }\end{array}$ & $\mathbf{( \%}$ & $\begin{array}{c}\boldsymbol{P} \text {. aeruginosa } \\
\text { ATCC } 27853\end{array}$ & $\begin{array}{c}\boldsymbol{P} \text {. aeruginosa } \\
\text { multiresisten } \\
\text { antibiotik }\end{array}$ & $\begin{array}{c}\text { S. aureus } \\
\text { ATCC } 25923\end{array}$ & $\begin{array}{c}\text { S. aureus multiresisten } \\
\text { antibiotik }\end{array}$ \\
\hline 4 & - & - & - & - \\
2 & - & - & - & - \\
1 & - & - & - & - \\
0,5 & + & + & - & - \\
0,25 & ++ & ++++ & + & - \\
0,125 & +++ & ++++ & ++++ & ++ \\
$\mathrm{K}+$ & ++++ & - & - & ++++ \\
$\mathrm{K}$ & & & - & - \\
\hline
\end{tabular}

Keterangan :

$(+)=$ Tumbuh

$\mathrm{K}-\quad=$ Kontrol negatif $(4,0 \mathrm{~mL}$ media $\mathrm{MH})$

$(-)=$ Tidak tumbuh

$\mathrm{K}+=$ Kontrol positif $(4,0 \mathrm{~mL}$ media $\mathrm{MH}+25 \mu \mathrm{L}$ suspensi bakteri)

Metode fraksinasi dalam penelitian ini adalah Kromatografi Cair Vakum (KCV). Pemasukan sampel dalam kolom KCV dilakukan tidak dalam bentuk larutan, melainkan dalam bentuk teradsorbsi atau diimpregnasi ke dalam silika gel agar luas permukaan kontak antara sampel dan eluen besar.
Pemilihan fase gerak dilakukan dengan didahului orientasi fase gerak. Orientasi dilakukan dengan melarutkan ekstrak aseton dengan metanol dan ditotolkan pada plat KLT kemudian dielusi dengan fase gerak yang berisi campuran antara n-heksana dan etil asetat dengan berbagai perbandingan. Hasil kromatogram memperlihatkan spot yang ditunjukkan pada Gambar 1.

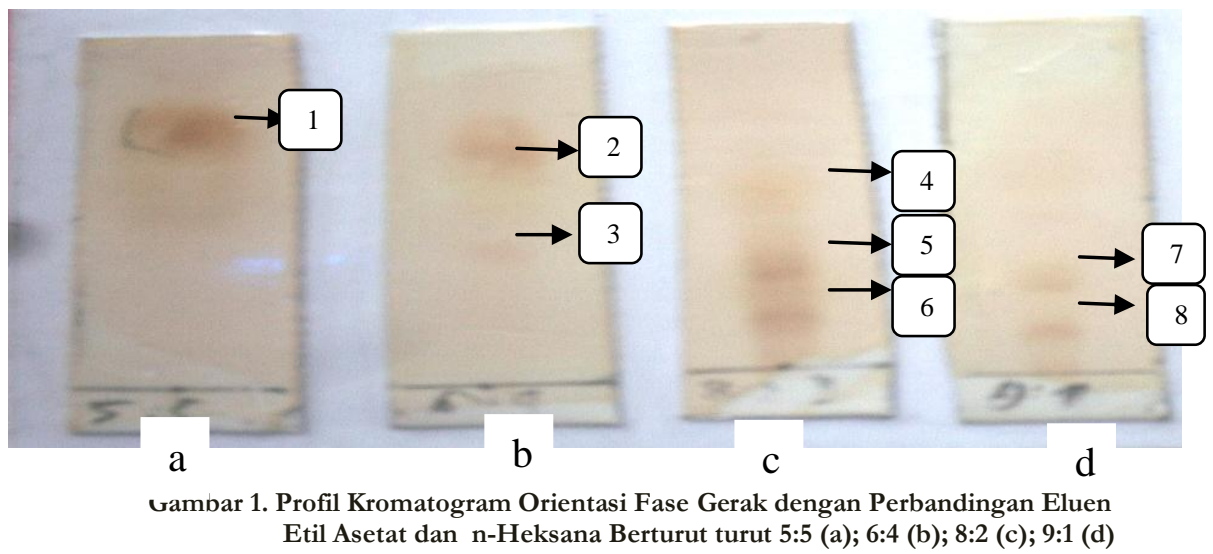

Gambar 1 memperlihatkan adanya perbedaan pola kromatogram pada setiap perbandingan eluen n-heksana dan etil asetat. Pada eluen $n$-heksana-etil asetat (5:5) yang ditunjukkan kromatogram a. Sementara dengan eluen n-heksana-etil asetat (6:4) yang ditunjukkan kromatogram b, terlihat dua spot terelusi dan terpisahkan dengan baik dengan Rf 0,63 dan 0,38. Kemudian kromatogram c terlihat adanya tiga spot dengan Rf berturut turut 0,$5 ; \quad 0,25$ dan 0,13. Terakhir kromatogram d hanya ada dua spot dengan $\operatorname{Rf} 0,23$ dan 0,1 . 
Tabel 3. Perhitungan Harga Rf Kromatogram Elusi Ekstrak Aseton

\begin{tabular}{cccc}
\hline Spot & Jarak yang ditempuh bercak & Jarak pengembangan & Harga Rf \\
\hline 1 & $3,0 \mathrm{~cm}$ & $4 \mathrm{~cm}$ & 0,75 \\
2 & $2,5 \mathrm{~cm}$ & $4 \mathrm{~cm}$ & 0,625 \\
3 & $1,5 \mathrm{~cm}$ & $4 \mathrm{~cm}$ & 0,375 \\
4 & $2,0 \mathrm{~cm}$ & $4 \mathrm{~cm}$ & 0,5 \\
5 & $1,0 \mathrm{~cm}$ & $4 \mathrm{~cm}$ & 0,25 \\
6 & $0,5 \mathrm{~cm}$ & $4 \mathrm{~cm}$ & 0,125 \\
7 & $0,9 \mathrm{~cm}$ & $4 \mathrm{~cm}$ & 0,225 \\
8 & $0,4 \mathrm{~cm}$ & $4 \mathrm{~cm}$ & 0,1 \\
\hline
\end{tabular}

Fokus pemisahan akan terjadi pada perbandingan eluen etil asetat dan n-heksana (6:4), (7:3), dan (8:2), maka digunakan masing-masing empat kali elusi. Untuk mendapatkan pemisahan yang relatif lebih baik, eluen n-heksana-etil asetat (5:5) digunakan sebanyak dua kali elusi. Untuk memastikan bahwa semua komponen terelusi, eluen $n$-heksana-etil asetat (9:1) digunakan dalam dua kali elusi, sedangkan untuk membersihkan kolom digunakan metanol.

Hasil fraksinasi yang mempunyai profil KLT yang sama (Gambar 2) digabung dan ditandai sebagai satu fraksi. Pada pemisahan ekstrak aseton kulit batang Shorea accuminatissima diperoleh empat fraksi (Tabel 4) kemudian ditentukan sifat fraksi tersebut apakah non polar, semi polar atau polar.

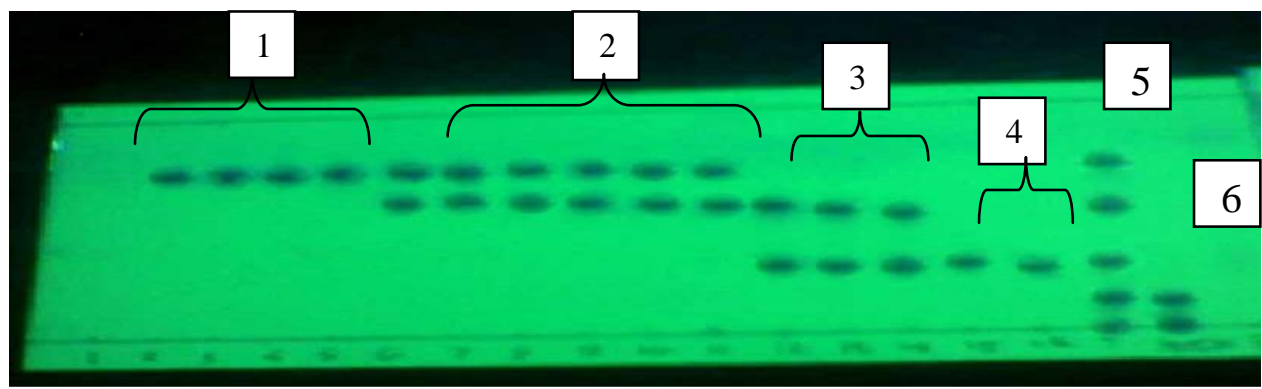

Gambar 2. Profil Kromatogram Hasil Fraksinasi KCV pada UV 254

Keempat fraksi yang diperoleh diuji bioautografi aktivitas antibakteri terhadap $P$. aeruginosa ATCC 27853 dan S. aureus ATCC 25923 untuk ditentukan fraksi yang aktif sebagai antibakteri untuk kemudian ditentukan kadar bunuh minimum (KBM)nya terhadap $P$. aeruginosa dan S.aureus multiresisten antibiotik.

Tabel 4. Fraksi Ekstrak Aseton

\begin{tabular}{cccc}
\hline No & Fraksi & Eluan & Berat fraksi kering (gram) \\
\hline 1 & A & $1,2,3,4,5$ & 1,739 \\
2 & B & $6,7,8,9,10,11$ & 1,0585 \\
3 & C & $12,13,14$ & 7,2958 \\
4 & D & 15,16 & 0,2191 \\
5 & Ekstrak Aseton & 17 & - \\
6 & Metanol & 18 & - \\
\hline
\end{tabular}

Metode bioautografi yang digunakan dalam penelitian ini adalah filter paper disk dengan menggunakan kertas saring yang diimpregnasi dengan masing-masing fraksi untuk kemudian ditanam dalam media yang telah mengandung inokulum bakteri. Adanya aktivitas antibakteri ditunjukkan dengan 
terdapatnya zona jernih (zone radical) pada

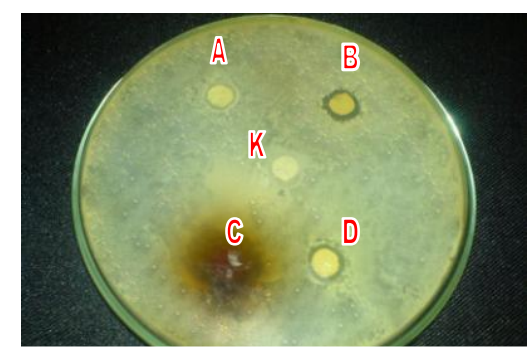

Gambar 3. Hasil Uji Bioautografi terhadap $P$. aeruginosa ATCC 27853

Keterangan :

A : impregnasi fraksi A $2,5 \mathrm{mg}$

B : impregnasi fraksi B $2,5 \mathrm{mg}$

C : impregnasi fraksi C $2,5 \mathrm{mg}$

Hasil uji bioautografi terhadap $P$. aeruginosa ATCC 27853 menunjukkan bahwa pada fraksi B, C dan D terdapat zona hambatan dengan diameter masingmasing 10; 16; $10 \mathrm{~mm}$. Sedangkan pada fraksi A dan kontrol negatif tidak terdapat zona hambatan. Hasil uji bioautografi terhadap S. aureus ATCC 25923 menunjukkan bahwa pada fraksi C terdapat zona hambatan dengan diameter $18 \mathrm{~mm}$. Sedangkan pada fraksi A, B, D dan kontrol negatif tidak terdapat zona hambatan. Semakin besar diameter zona hambat, semakin besar pula aktivitas antibakterinya. Dengan demikian fraksi $C$ yang memiliki zona hambatan terbesar merupakan fraksi aktif antibakteri media agar yang telah diinokulasi bakteri.

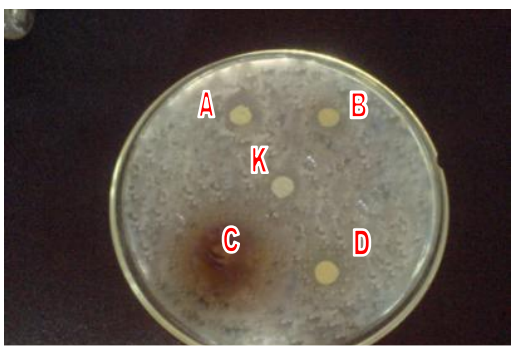

Gambar 4. Hasil Uji Bioautografi terhadap S. aureus ATCC 25923

D : impregnasi fraksi D 2,5 mg

$\mathrm{K}$ : Kontrol, disk kertas saring steril

terhadap P. aeruginosa ATCC 27853 dan S. aureus ATCC 25923.

Hasil uji aktivitas antibakteri fraksi aktif ekstrak aseton kulit batang meranti kuning terhadap S. aureus ATCC 25923 dan $S$. aureus multiresisten antibiotik menunjukkan bahwa ekstrak aseton memberikan nilai KBM sebesar 0,125 \% $\mathrm{b} / \mathrm{v}$. Sedangkan hasil uji aktivitas antibakteri ekstrak aseton kulit batang meranti kuning dapat terhadap $P$. aeruginosa ATCC 27853 dan P. aeruginosa multiresisten antibiotik menunjukkan bahwa ekstrak aseton memberikan nilai $\mathrm{KBM}$ sebesar 0,25\% b/v. hasil tersebut dapat dilihat pada Tabel 5.

Tabel 5. Hasil Uji Aktivitas Antibakteri Ekstrak Aseton Kulit Batang Meranti Kuning (Shorea accuminatissima) terhadap $S$. aureus ATCC 25923, P. aeruginosa ATCC 27853, S. aureus dan $P$. aeruginosa Multiresisten Antibiotik.

\begin{tabular}{cccccc}
\hline $\begin{array}{c}\text { Konsentrasi } \\
\text { b/v) }\end{array}$ & $\begin{array}{c}(\% \text {. aeruginosa } \\
\text { ATCC } 27853\end{array}$ & $\begin{array}{c}\text { P. aeruginosa } \\
\text { multiresisten } \\
\text { antibiotik }\end{array}$ & $\begin{array}{c}\text { S. aureus } \\
\text { ATCC 25923 }\end{array}$ & $\begin{array}{c}\text { S. aureus } \\
\text { multiresisten } \\
\text { antibiotik }\end{array}$ \\
\hline 1 & - & - & - & - \\
0,5 & - & - & - & - \\
0,25 & - & - & - & - \\
0,125 & ++ & ++ & - & - \\
0,0625 & +++ & +++ & + & + \\
$\mathrm{K}+$ & ++++ & ++++ & ++++ & ++++ \\
$\mathrm{K}$ & & - & - & - \\
\hline
\end{tabular}

Keterangan :
$(+)=$ Tumbuh
$(-)=$ Tidak tumbuh
$\mathrm{K}-\quad=$ Kontrol negatif $(4,0 \mathrm{~mL}$ media $\mathrm{MH})$

$\mathrm{K}+=$ Kontrol positif $(4,0 \mathrm{~mL}$ media $\mathrm{MH}+25 \mu \mathrm{L}$ suspensi bakteri) 
Bakteri S. aureus merupakan bakteri yang mewakili Gram positif, dan P.aeruginosa merupakan bakteri Gram negatif meskipun lapisan peptidoglikannya tebal, $S$. aureus tidak mempunyai selaput luar yang berfungsi untuk mencegah kebocoran dari protein periplasma dan melindungi sel dari garam-garam empedu dan enzim-enzim hidroksi lingkungan luar seperti pada $P$. aeruginosa. Hal ini menyebabkan $P$. aeruginosa yang merupakan Gram negatif relatif tahan terhadap antibiotik atau senyawa-senyawa pengganggu lain dari luar dalam penelitian ini adalah senyawa yang terkandung dalam fraksi aktif yaitu fraksi C. P. aeruginosa lebih resisten terhadap disinfektan dari pada kuman lain. Kebanyakan antibiotik dan antimikroba tidak efektif terhadap $P$. aeruginosa (Jawetz et al, 2001), sehingga senyawa aktif yang terdapat pada fraksi aktif ekstrak aseton kulit batang Shorea accuminatissima lebih mudah menembus dinding sel $S$. aureus multiresisiten antibiotik dibandingkan dengan dinding sel $P$. aeruginosa multiresisten antibiotik.

Bakteri kokus Gram positif memproduksi enzim degradatif (autolisin) yang berpartisipasi dalam remodeling dinding sel bakteri normal. Dengan adanya senyawa tertentu, aksi degradatif autolisin didahului dengan hilangnya sintesis dinding sel. Mekanisme autolitik yang sebenarnya tidak diketahui tetapi kemungkinan adanya penghambatan yang salah dari autolysin sehingga, efek antibakteri merupakan hasil penghambatan sintesis dinding sel bakteri dan destruksi keberadaan dinding sel oleh autolisin (Mycek et al., 1995).

Kandungan senyawa dalam fraksi aktif (fraksi C) ekstrak aseton kulit batang S.accuminatissima menurut Sugiyarto (2007) adalah senyawa fenolik. Senyawa fenolik dalam menghambat pertumbuhan bakteri yaitu dengan cara mendenaturasi dan mengkoagulasi protein. Turunan fenol berinteraksi dengan sel bakteri melalui mekanisme adsorpsi yang melibatkan ikatan hidrogen dengan gugus fenol. Pada kadar rendah terbentuk komplek protein yang terdapat pada dinding sel bakteri dengan fenol yang ikatannya lemah dan segera mengalami peruraian, diikuti penetrasi fenol ke dalam sel dan menyebabkan presipitasi serta denaturasi protein plasma. Pada kadar tinggi fenol mempengaruhi permeabilitas membran sel sehingga menimbulkan kebocoran dan kehilangan senyawa intraselluler (Kuswandi et al., 2000).

Hasil dari uji antibakteri pada ekstrak aseton kulit batang meranti kuning (Shorea accuminatissima) maupun fraksi aktifnya menunjukkan bahwa pada fraksi aktif ekstrak aseton memiliki aktivitas antibakteri lebih tinggi daripada ekstraknya. Hal ini dimungkinkan karena dalam ekstrak masih terdapat senyawa yang sangat kompleks, sehingga kadar senyawa yang bertanggungjawab terhadap aktivitas antibakteri yaitu senyawa fenolik sangat kecil. Berbeda dengan fraksi aktifnya yang susunan senyawanya lebih sederhana, hanya terdiri atas kumpulan senyawa fenolik. Sehingga kadar senyawa fenolik dalam fraksi aktif ekstrak aseton lebih tinggi daripada ekstraknya. Selain itu hasil uji antibakteri pada ekstrak aseton kulit batang Shorea accuminatissima maupun fraksi aktifnya terhadap $S$. aureus ATCC 25923 dan S. aureus multiresisten antibiotik memberikan nilai KBM yang sama. Demikian pula terhadap $P$. aeruginosa ATCC 27853 dan P. aeruginosa multiresisten antibiotik memberikan nilai KBM yang sama. Hal ini dimungkinkan karena senyawa yang terkandung dalam ekstrak maupun fraksi aktifnya mempunyai mekanisme antibakteri dan tingkat sensitivitas yang sama. Dengan kata lain, bakteri yang bersifat multiresisten antibiotik belum mempunyai mekanisme pertahanan diri (resistensi) terhadap senyawa antibakteri yang terkandung dalam ekstrak maupun fraksi aktifnya.

\section{Kesimpulan dan Saran}

\section{A. Kesimpulan}

1. Konsentrasi Bunuh Minimum (KBM) dari ekstrak aseton kulit 
batang Shorea accuminatissima terhadap Staphylococcus aureus multiresisten antibiotik adalah $0,25 \% \mathrm{~b} / \mathrm{v}$ dan terhadap Pseudomonas aeruginosa multiresisten antibiotik adalah 1\% $\mathrm{b} / \mathrm{v}$.

2. Fraksi aktif ekstrak aseton kulit batang Shorea accuminatissima yang mempunyai aktivitas antibakteri tertinggi adalah fraksi C.

3. Konsentrasi Bunuh Minimum (KBM) dari fraksi aktif ekstrak aseton kulit batang meranti kuning (Shorea accuminatissima) terhadap Staphylococcus aureus multiresisten antibiotik adalah $0,125 \% \mathrm{~b} / \mathrm{v}$ dan terhadap Pseudomonas aeruginosa multiresisten antibiotik adalah $0,25 \%$ $\mathrm{b} / \mathrm{v}$.

\section{B. Saran}

1. Perlu dilakukan pengujian aktivitas antimikroba terhadap bakteri jenis lain pada ekstrak maupun fraksi aktif ekstrak aseton kulit batang Shorea accuminatissima.

2. Perlu dilakukan isolasi senyawa murni dari fraksi C untuk kemudian diuji aktivitas antibakterinya.

\section{Ucapan Terima Kasih}

1. Drs. Haryoto Saroyobudiyono, M.Sc., selaku pembimbing utama yang telah memberikan banyak bimbingan dan arahan.

2. Peni Indrayudha, S.F., Apt., selaku pembimbing pendamping yang telah memberikan banyak bimbingan dan arahan.

\section{DAFTAR PUSTAKA}

Gibson, J.M., 1996, Mikrobiologi dan Patologi Modern untuk Perawat, diterjemahkan oleh IKG Soma Persada, I, Penerbit Kedokteran EGC, Jakarta.

Hertiani T., Palupi, I.S., Sanliferianti, Nurwindasari, H.D., 2003, Uji Potensi Antimikroba terhadap
S. aureus, E. coli, Shigella dysentriae, dan Candida albicans dari Beberapa Tanaman Obat Tradisional untuk Penyakit Infeksi, Pharmacon, vol. 4 no.2, UMS, Surakarta.

Ito, Tetsuro., Furusawa, M., Iliya, I., Tanaka, T., Ichi N. K., Sawa, R., Kubota, Y., Takahashi, Y., Riswan, S., Iinuma, M., 2005, Rotational Isomerism of a Resveratrol Tetramer, Shoreaketone, in Shorea uliginosa, Tetrahedron Letters, 46 : 31113114.

Ito, Tetsuro., Tanaka, T., Iinuma, M., Ichi N. K., Takahashi, Y., Sawa, R., Naganawa, H., Chelladurai, V., 2003, Two New Oligostilbenes with Dihydrobenzofuran from the Stem Bark of Vateria indica, Tetrahedron, 59: 1255-1264.

Jawetz, E, Melnick, J.L., Adelberg, E.A., 2001, Mikrobiologi Kedokteran, edisi I diterjemahkan bagian mikrobiologi Fakultas Kedokteran UNAIR, 224-227, 233-235, Salemba Medika, Surabaya.

Kuswandi, M., Iravati, S., Rahayu, T.D.R., Setyaningsih, A., 2000, Daya Antibakteri Minyak Adas Manis (Foeniculum vulgare) terhadap Bakteri Resisten Antibiotik, Pharmacon, vol. 1, No. 2, Desember 2000, 36 -41.

Mycek, M. J., Harvey, R. A., Champe, P. C., 1995, Farmakologi : Ulasan Bergambar, diterjemahkan oleh Azwar Agoes, 2 ${ }^{\text {nd }}$ edition, Widya Medika, Jakarta.

Noviany, Hakim, E.H., Achmad, S.A., Syah, Y.M., Juliawaty, L.D., Aimi, N, Ghisalberty, E.L.,Choudhary, I.M., 2003, Beberapa Oligomer Stilbenoid dari Tumbuhan Shorea multiflora (Bruck), Bulletin Society Natural Product Chemical (Indonesia), ITB, Bandung. 
Shulman, S. T., Phair, J. P., Sommers, H. M., 1994, Dasar Biologi dan Klinis Penyakit Infeksi, diterjemahkan oleh Sawik Wahab, GMU Press, Yogyakarta.

Sotheeswaran S. and Pasupathy V., 1993, Distribution of Resveratrol Oligomer in Plants, Phytochemistry, 32(5) : 1083-1092.

Sugiyarto, 2007, Uji Aktivitas Antijamur Fraksi B dan Fraksi C Ekstrak Aseton Kulit Batang Meranti Kuning (Shorea accuminatissima) terhadap

Trichophyton mentagrophytes ATCC 9533,

Skripsi, Universitas

Muhammadiyah Surakarta,

Surakarta.

Sultanbawa, M.U.S., Surendrakumar, S., dan Bladon, P., 1987, Distichol, An Antibacterial Polyphenol From Shorea disticha, Phytochemistry, 26, 799-801.

Wattimena, J.R., 1991, Farmakodinamis dan Terapi Antibiotik, Gadjah Mada University Press, Yogyakarta, 48. 